\title{
KARAKTERISTIK PENYELESAIAN PERSELISIHAN HUBUNGAN INDUSTRIAL MELALUI PENGADILAN HUBUNGAN INDUSTRIAL
}

\author{
Suhandi \\ Fakultas Hukum Universitas Wijaya Kusuma Surabaya \\ e-mail: suhandifh@gmail.com
}

\begin{abstract}
ABSTRAK
Pengadilan Hubungan Industrial sebagai pengadilan khusus yang berada pada pengadilan umum mempunyai karakteristik tersendiri dalam penyelesaian sengketa dibandingkan dengan perkara perdata pada umumnya, penelitian ini bertujuan untuk mengetahui dan menganalisis ciri khusus penyelesaian sengketa melalui Pengadilan Hubungan Industrial. Penelitian ini merupakan penelitian normatif. Hasil penelitian ditemukan adanya beberapa karakteristik dalam penyelesaian perselisihan hubungan industrial melalui Pengadilan Hubungan Industrial sebagai berikut: Obyek perselisihannya meliputi di tingkat pertama mengenai perselisihan hak, di tingkat pertama dan terakhir mengenai perselisihan kepentingan, di tingkat pertama mengenai perselisihan pemutusan hubungan kerja, di tingkat pertama dan terakhir mengenai perselisihan antar serikat pekerja dalam suatu perusahaan. Subyek perselisihan meliputi: Pekerja, Pengusaha baik berbentuk Perseroan Terbatas maupun Perorangan, Serikat Pekerja, mengenai lembaga peradilannya meliputi Hakim Karier dan Hakim Ad Hoc, sedangkan mengenai hukum acara adalah hukum acara perdata sepanjang tidak diatur secara khusus oleh Undang-Undang Nomor 2 Tahun 2004 tentang Penyelesaian Perselisihan Hubungan Industrial, dalam pengajuan gugatan wajib dilampiri risalah anjuran baik dari mediasi maupun konsiliasi dan menyangkut kuasa hukum, serikat pekerja/buruh dan asosiasi pengusaha bisa bertindak sebagai kuasa hukum untuk mewakili kepentingan anggotanya, hal-hal tersebut yang membedakan penyelesaian perselisihan hubungan industrial melaui Pengadilan Hubungan Industrial dengan perkara perdata pada umum.
\end{abstract}

Kata Kunci: Karakteristik, Penyelesaian perselisihan, Pengadilan Hubungan Industrial.

\begin{abstract}
The Industrial Relations Court as a special court in a public court has its own characteristic in dispute resolution compared to general civil cases, this study aims to identify and analyze the specific characteristics of dispute resolution through the Industrial Relations Court. This research is a normative research. The results of the research found that there are several characteristics in the settlement of industrial relations disputes through the Industrial Relations Court as follows: The object of the dispute covers the first level concerning the rights disputed, the first and final level is the interest disputes, the first level is the dismissal disputes, the first and the final dispute is between trade unions within a company. The subject of the dispute shall include: Workers, Entrepreneurs in the form of Limited Liability Companies and Individuals, Trade Unions, on judicial institutions including Career Judges and Ad Hoc Judges, whereas the procedural law is a civil procedure law insofar as it is not specifically regulated by Law Number 2 Year 2004 about Industrial Relations Disputes Settlement, in the forming of a lawsuit shall be accompanied by a recommendation note of both mediation and conciliation and concerning legal representation, trade unions and employers' associations may act as a legal representative to represent the interests of its members, those which distinguish the settlement of industrial relations disputes through Industrial Relations Court with common civil case.
\end{abstract}

Keywords: Characteristics, Dispute resolution, Industrial Relations Court. 


\section{PENDAHULUAN}

Sebagai negara yang berkembang, Indonesia melaksanakan pembangunan di bidang hukum ketenagakerjaan yang sangat diharapkan oleh seluruh masyarakat Indonesia khususnya pekerja dan pengusaha.

Pembangunan ketenagakerjaan sebagai bagian dari pembangunan nasional dilaksanakan dalam rangka pembangunan manusia Indonesia seutuhnya dan pembangunan masyarakat Indonesia seluruhnya untuk meningkatkan harkat, martabat tenaga kerja, untuk itu perlu adanya pengaturan hukum yang lebih efektif sehingga dapat terpenuhi hak-hak, kewajiban dan perlindungan yang mendasar bagi pekerja dan pengusaha.

Kebijaksanaan di dalam ketenagakerjaan yang menyebutkan pembinaan hubungan kerja dari pengusaha perlu terus ditingkatkan pada terciptanya kerjasama yang serasi dan seimbang yang dijiwai oleh Pancasila dan Undang-Undang Dasar 1945, masing-masing pihak saling memahami peranan serta melaksanakan hak dan kewajiban masing-masing.

Hubungan Industrial yang harmonis, seimbang, dan berkeadilan antara pekerja dengan pengusaha diperlukan adanya seperangkat peraturan perundangundangan sebagai pedoman bersikap bagi pekerja dan pengusaha dalam melaksanakan hubungan industrial dan menjaga hak dan kewajiban masingmasing pihak dan dijadikan juga sebagai pedoman apabila terjadi perselisihan hubungan industrial.

Pengadilan Hubungan Industrial (yang selanjutnya disingkat PHI) adalah pengadilan khusus yang mempunyai karakteristik tersendiri dibandingkan dengan peradilan umum lainnya, adapun karakteristiknya tersebut dapat terlihat dari: ${ }^{1}$

Pertama, Obyek perselisihan hubungan industrial di tingkat pertama mengenai perselisihan hak, adalah perselisihan yang timbul karena tidak dipenuhinya hak akibat adanya perbedaan pelaksanaan atau penafsiran terhadap ketentuan peraturan perusahaan, atau perjanjian kerja bersama, perselisihan hak ini disebut sebagai perselisihan normatif, yaitu perselisihan terhadap norma-norma yang diatur dalam peraturan hukum ketenagakerjaan;

\footnotetext{
${ }^{1}$ Naskah Akademis, Penyelesaian Perselisihan Hubungan Industrial, Puslitbang Hukum dan Peradilan, Badan Litbang Diklat Kumdil, Mahkamah Agung RI, 2007, h. 20.
}

Kedua, di tingkat pertama dan terakhir mengenai perselisihan kepentingan, adalah perselisihan yang timbul dalam hubungan kerja karena tidak adanya kesesuaian pendapat mengenai pembuatan, dan atau perubahan syarat-syarat kerja yang ditetapkan dalam perjanjian kerja, atau peraturan perusahaan, atau perjanjian kerja bersama;

Ketiga, di tingkat pertama mengenai perselisihan pemutusan hubungan kerja, adalah perselisihan yang timbul karena tidak adanya kesesuaian pendapat mengenai pengakhiran hubungan kerja yang dilakukan oleh salah satu pihak;

Keempat, di tingkat pertama dan terakhir mengenai perselisihan antar serikat pekerja dalam suatu perusahaan, adalah perselisihan antar serikat pekerja/serikat buruh dengan serikat pekerja/serikat buruh dengan serikat pekerja/serikat buruh lainnya hanya dalam satu perusahaan karena tidak adanya persesuaian mengenai keanggotaan, pelaksanaan hak dan kewajiban keserikatpekerjaan.

Adapun subjek hukum perselisihan hubungan industrial merupakan pihak yang mempunyai kedudukan hukum atau legal standing yang bisa menjadi pihak dalam perselisihan hubungan industrial di PHI, yaitu: ${ }^{2}$

Pertama, Pengusaha atau gabungan pengusaha mempunyai kriteria sebagai berikut: Orang per orang tertentu, persekutuan, atau badan hukum yang menjalankan suatu perusahaan milik sendiri yang berada di wilayah Indonesia; dan berdiri sendiri menjalankan perusahaan bukan miliknya apabila berkedudukan di luar wilayah Indonesia.

Kedua, Pekerja perseorangan merupakan setiap orang yang bekerja dengan menerima upah atau imbalan dalam bentuk lain. Sedangkan, Serikat pekerja/serikat buruh merupakan organisasi yang dibentuk dari, oleh, dan untuk pekerja baik di perusahaan maupun di luar perusahaan yang bersifat bebas, terbuka, mandiri, demokratis, dan bertanggungjawab guna memperjuangkan, membela serta melindungi kepentingan pekerja serta meningkatkan kesejahteraan pekerja dan keluarganya.

Ketiga, Usaha-usaha sosial dan usaha-usaha yang tidak berbentuk lain perusahaan tetapi mempunyai

\footnotetext{
${ }^{2}$ Ibid., h. 22.
} 
pengurus dan mempekerjakan orang lain dengan membayar upah.

Kebutuhan di masyarakat Indonesia pada saat ini untuk penyelesaian perselisihan hubungan industrial telah mengalami banyak perubahan, antara lain dengan diundangkannya Undang-Undang No. 2 Tahun 2004 tentang Penyelesaian Perselisihan Hubungan Industrial. Diundangkannya undangundang ini dengan latar belakang bahwa UndangUndang No. 22 Tahun 1957 tentang Penyelesaian Perselisihan Perburuhan dan Undang-Undang Nomor 12 Tahun 1964 tentang Pemutusan Hubungan Kerja di Perusahaan Swasta sudah tidak sesuai lagi dengan kebutuhan masyarakat, sedangkan di era indutrialisasi ini masalah perselisihan hubungan industrial semakin meningkat dan kompleks sehingga diperlukan lembaga dan mekanisme penyelesaian perselisihan hubungan industrial yang cepat, murah, sederhana, dan berkeadilan. Perubahan mekanisme penyelesaian perselisihan hubungan industrial telah menambah kekuasaan kehakiman baru, dan ini menjadi penting untuk dicermati ciri atau karakteristik penyelesaian perselisihan hubungan industrial melalui PHI yang membedakan penyelesaian perkara perdata pada umumnya.

Berdasarkan ketentuan Pasal 59 Undang-Undang No. 2 Tahun 2004 tersebut ditentukan bahwa untuk pertama kali dengan undang-undang ini dibentuk PHI pada setiap Pengadilan Negeri Kabupaten/Kota yang berada pada setiap Ibukota Propinsi yang daerah hukumnya meliputi propinsi yang bersangkutan, namun demikian kabupaten/kota yang padat industri dengan Keputusan Presiden segera dibentuk PHI pada Pengadilan Negeri setempat, yang dimaksud dengan kata segera berdasarkan penjelasan Pasal 59 ayat (2) Undang-Undang No. 2 Tahun 2004, adalah dalam waktu 6 (enam) bulan sesudah undang-undang ini berlaku, dan di dalam prakteknya hingga sekarang keberadaan PHI baru terbatas pada Pengadilan Negeri Ibukota Propinsi, kecuali PHI pada Pengadilan Negeri Gresik dibentuk berdasarkan Keputusan Presiden No. 29 Tahun 2011 tentang Pembentukan PHI pada Pengadilan Negeri Gresik.
Jabatan Struktur PHI pada Pengadilan Negeri terdiri atas: ${ }^{3}$ Hakim; Hakim Ad Hoc; Panitera Muda; Panitera Pengganti, dan Juru Sita.

Sebagai lembaga pengadilan, hakim memegang peran penting dalam rangka menegakkan hukum dan keadilan, demikian juga dengan hakim pada PHI. Hakim pada PHI terdiri dari hakim karier pada pengadilan negeri yang ditugasi pada PHI dan hakim Ad-Hoc, yakni hakim atas usul serikat pekerja/serikat buruh dan atas usul organisasi pengusaha. Hakim PHI pada Pengadilan Negeri diangkat dan diberhentikan berdasarkan Keputusan Mahkamah Agung (Pasal 61 Undang-Undang No. 2 Tahun 2004). Hakim AdHoc PHI diangkat dengan Keputusan Presiden atas usul Ketua Mahkamah Agung. Calon hakim Ad-Hoc diajukan oleh ketua Mahkamah Agung dari daftar nama yang disetujui oleh Menteri Tenaga Kerja atas usul serikat pekerja/serikat buruh atau organisasi pengusaha.

Untuk dapat diangkat menjadi Hakim Ad-Hoc pada PHI dan Hakim Ad-Hoc pada Mahkamah Agung, harus memenuhi syarat sebagai berikut: Warga Negara Indonesia; Bertakwa kepada Tuhan Yang Maha Esa; Setia kepada Pancasila dan UUD 1945; Berumur paling rendah 30 (tiga puluh) tahun; Berbadan sehat sesuai dengan keterangan dokter; Berwibawa, jujur, adil, dan berkelakuan tidak tercela; Berpendidikan serendah-rendahnya Strata Satu (S1) kecuali bagi Hakim Ad-Hoc pada Mahkamah Agung syarat pendidikan Sarjana Hukum; dan Berpengalaman di bidang hubungan industrial minimal 5 (lima) tahun.

Sebelum memangku jabatannya, Hakim Ad-Hoc PHI wajib mengucapkan sumpah atau janji menurut agama atau kepercayaannya.

Hakim Ad-Hoc tidak boleh merangkap jabatan sebagai: Anggota Lembaga Tinggi Negara; Kepala Daerah/Kepala Wilayah; Lembaga legislatif tingkat daerah; Pegawai Negeri Sipil; Anggota TNI/Polri; Pengurus partai politik; Pengacara; Mediator; Konsiliator; Arbiter; atau Pengurus serikat pekerja/ serikat buruh atau pengurus organisasi pengusaha.

Jika ada seorang hakim Ad-Hoc yang merangkap jabatan yang sebagaimana dimaksud di atas, jabatannya sebagai hakim Ad-Hoc dapat dibatalkan,

\footnotetext{
${ }^{3}$ Lilik Mulyadi dan Agus Subroto, Penyelesaian Perkara Pengadilan Hubungan Industrial dalam Teori dan Praktik, Alumi, Bandung, 2011, h. 5.
} 
mengingat persyaratan untuk dapat menjadi hakim Ad-Hoc pada PHI sebagaimana tersebut atas, maka tidak terlalu sulit untuk mendapatkan sumber daya manusia yang akan direkrut untuk menjadi hakim Ad-Hoc. Namun kesulitan mulai muncul setelah melihat ketentuan larangan jabatan rangkap dari hakim Ad-Hoc. Banyak yang berpengalaman dalam bidang hubungan industrial lebih dari 5 tahun serta memahami ketentuan perundang-undangan di bidang ketenagakerjaan, tapi yang bersangkutan adalah pegawai negeri sipil (kalangan kampus), pengacara, pengurus serikat pekerja/serikat buruh atau organisasi pengusaha yang sebelumnya aktif sebagai anggota panitia penyelesaian perselisihan perburuhan daerah/pusat. Karena itu, bagi pihakpihak yang berkeinginan menjadi hakim Ad-Hoc pada PHI dari sekarang harus sudah mengantisipasi persyaratan-persyaratan tersebut. ${ }^{4}$

Kepaniteraan dalam pengadilan merupakan salah satu bagian yang terpenting khususnya dalam penyelenggaran teknis administrasi pengadilan maupun kelengkapan jalannya persidangan. Karena itu, Undang-Undang No. 2 Tahun 2004 mengatur mengenai hal ini mulai dari Pasal 74 sampai dengan Pasal 80.

Pada setiap PHI pada Pengadilan Negeri dibentuk sub kepaniteraan PHI yang dipimpin oleh seorang panitera muda dengan dibantu oleh beberapa orang Panitera Pengganti.

Untuk pertama kali panitera muda dan panitera pengganti PHI diangkat dari pewagai negeri sipil dari instansi pemerintah yang bertanggungjawab di bidang ketenagakerjaan, ${ }^{5}$ persyaratan tata cara pengangkatan dan pemberhentian panitera muda dan panitera pengganti PHI di atur lebih lanjut menurut peraturan perundang-undangan yang berlaku. Panitera pengganti bertugas mencatat jalanan persidangan dalam berita acara persidangan. Berita acara tersebut ditandatangani hakim dan panitera pengganti.

Hakim Ad-Hoc PHI dan Hakim Ad-Hoc Hubungan Industrial pada Mahkamah Agung dapat diberhentikan dengan hormat dari jabatannya karena:

${ }^{4}$ Lalu Husni, Penyelesaian Perselisihan Hubungan Industrial melalui Pengadilan dan di Luar Pengadilan, Raja Grafindo Persada, Jakarta, 2004, h. 92.

${ }^{5}$ Pasal 77 Undang-Undang No. 2 Tahun 2004 tentang Penyelesaian Perselisihan Hubungan Industrial.
Meninggal dunia; Permintaan sendiri; Sakit jasmani atau rohani terus menerus selama 12 (dua belas) bulan; Telah berumur 62 (enam puluh dua) tahun bagi Hakim Ad-Hoc pada PHI dan telah berumur 67 (enam puluh tujuh) tahun bagi Hakim AdHoc pada Mahkamah Agung; Tidak cakap dalam menjalankan tugas; Atas permintaan organisasi pengusaha atau organisasi pekerja/organisasi buruh yang mengusulkan; atau Telah selesai masa tugas. ${ }^{6}$

Selain dengan cara terhormat, Hakim Ad-Hoc PHI juga dapat diberhentikan tidak dengan hormat dari jabatannya dengan alasan: Dipidana karena bersalah melakukan tindak pidana kejahatan; Selama 3 (tiga) kali berturut-turut dalam kurun waktu 1 (satu) bulan melalaikan kewajiban dalam menjalankan tugas pekerjaannya tanpa alasan yang sah; atau Melanggar sumpah atau janji jabatan; Pemberhentian tidak dengan hormat dengan alasan sebagaimana dimaksud di atas, dilakukan setelah yang bersangkutan diberi kesempatan untuk mengajukan pembelaan kepada Mahkamah Agung.

Setelah mengetahui mengenai kedudukan hukum PHI dalam sistem tata hukum di Indonesia serta prosedur administrasi mengenai hakim AdHoc PHI pada Pengadilan Negeri maupun pada Mahkamah Agung. Maka perlu kita ketahui mengenai pelaksanaan penyelesaian perselisihan hubungan industrial melalui PHI.

\section{PERUMUSAN MASALAH}

Berdasarkan pada uraian latar belakang tersebut, maka dapat dirumuskan permasalah dalam penelitian ini adalah bagaimanakah karakteristik penyelesaian perselisihan hubungan industrial melalui PHI.

\section{METODE PENELITIAN}

Penelitian ini menggunakan metode penelitian normatif, yaitu dengan meneliti berbagai peraturan perundang-undangan yang digunakan sebagai dasar ketentuan hukum, ada beberapa pendekatan, dengan pendekatan tersebut, peneliti akan mendapatkan informasi dari berbagai aspek mengenai isu hukum yang sedang diteliti untuk mencari jawabannya pendekatan yang digunakan dalam penelitian ini adalah pendekatan undang-undang atau statute

${ }^{6}$ Pasal 67 Undang-Undang No. 2 Tahun 2004 tentang Penyelesaian Perselisihan Hubungan Industrial. 
approach, ${ }^{7}$ dengan bahan hukum yang digunakan adalah bahan hukum primer berupa peraturan perundang-undangan yang terkait dengan penelitian dan bahan hukum sekunder berupa, buku-buku electronic research, jurnal-jurnal hukum, dan pendapat para pakar hukum.

\section{PEMBAHASAN}

Hukum Acara Pengadilan Hubungan Industrial

Hukum acara yang digunakan dalam PHI adalah hukum acara perdata sepanjang tidak diatur khusus oleh Undang-Undang No. 2 Tahun 2004 (Pasal 57 Undang-Undang No. 2 Tahun 2004), dengan demikian dalam prakteknya menggunakan HIR maupun Rbg. Gugatan wajib dilampiri risalah penyelesaian melalui mediasi atau konsiliasi (Pasal 81 Undang-Undang No. 2 Tahun 2004). Penundaan sidang karena ketidakhadiran salah satu pihak atau para pihak yang dipanggil secara sah, hanya diberikan sebanyak-banyaknya 2 (dua) kali penundaan (Pasal 93 ayat (3) Undang-Undang No. 2 Tahun 2004).

Batasan waktu pemeriksaan, Majelis Hakim wajib memberikan pututsan penyelesaian perselisian hubungan industrial dalam waktu selambatlambatnya 50 (lima puluh) hari kerja terhitung sejak sidang pertama (Pasal 103 Undang-Undang No. 2 Tahun 2004). Selambat-lambatnya 14 (empat belas) hari kerja setelah putusan ditandatangani Panitera Muda harus sudah menerbitkan salinan putusan (Pasal 107 Undang-Undang No. 2 Tahun 2004).

Putusan PHI mengenai perselisihan kepentingan dan perselisihan antar serikat pekerja/serikat buruh dalam satu perusahaan merupakan putusan akhir dan bersifat final (Pasal 109 Undang-Undang No. 2 Tahun 2004). Tidak dikenakan biaya perkara untuk obyek sengketa di bawah Rp. 150.000.000,- (seratus lima puluh juta rupiah) (Pasal 58 Undang-Undang No. 2 Tahun 2004).

Kuasa Hukum dalam Pengadilan Hubungan Industrial mendasarkan pada ketentuan Pasal 2 Undang-Undang No. 18 Tahun 2003 tentang Advokat, menyatakan bahwa yang dapat diangkat sebagai Advokat adalah sarjana yang berpendidikan tinggi hukum dan setelah mengikuti pendidikan khusus profesi Advokat yang dilaksanakan oleh Organisasi Advokat.
Sedangkan ketentuan dalam Pasal 87 UndangUndang No. 2 Tahun 2004 tentang Penyelesaian Perselisihan Hubungan Industrial, memberikan kesempatan kepada pengurus serikat pekerja/ serikat buruh dan organisasi pengusaha untuk dapat bertindak sebagai kuasa hukum mewakili anggotanya di persidangan, yang dimaksud pengurus serikat pekerja/serikat buruh adalah meliputi pengurus tingkat perusahaan, pengurus tingkat kabupaten/ kota, pengurus tingkat propinsi maupun pengurus tingkat pusat.

\section{Tahapan Proses Penyelesaian Perselisihan Hubungan Industrial melalui Pengadilan Hubungan Industrial}

Dalam Pasal 1 angka 1 Undang-Undang No. 2 Tahun 2004 tentang Penyelesaian Perselisihan Hubungan Industrial, menegaskan bahwa perbedaan pendapat yang mengakibatkan pertentangan antara pengusaha atau gabungan pengusaha dengan pekerja atau serikat pekerja/serikat buruh karena adanya perselisihan mengenai hak, perselisihan kepentingan, perselisihan pemutusan hubungan kerja dan perselisihan antar serikat pekerja atau serikat buruh hanya dalam satu perusahaan. Terdapat tahapan-tahapan dalam penyelesaian perselisihan hubungan industrial. Tahapan pertama wajib dilakukan Perundingan Bipartit, tahapan kedua yaitu penyelesaian perselisihan melalui Konsiliasi, dan tahapan ketiga penyelesaian melalui Mediasi

Penyelesaian secara bipartit dalam kepustakaan mengenai Alternative Dispute Resulution (ADR) disebut penyelesaian secara negosiasi, kata negosiasi berasal dari bahasa Inggris negotiation yang berarti perundingan atau musyawarah, secara umum negosiasi berarti upaya penyelesaian sengketa oleh para pihak dengan tanpa melibatkan pihak ketiga dengan tujuan mencari kesepakatan bersama, negosiasi merupakan komunikasi dua arah yang dirancang untuk mencapai kesepakatan pada saat para pihak mengalami konflik.

Negosiasi adalah sarana bagi para pihak yaitu pihak pengusaha maupun pihak pekerja yang bersengketa untuk mendiskusikan penyelesaian tanpa keterlibatan dari pihak lain sebagai perantara.

${ }^{7}$ Peter Mahmud Marzuki, Penelitian Hukum, Prenada Media, Jakarta, 2005, h. 95. 
Berdasarkan Kamus Besar Bahasa Indonesia ${ }^{8}$ negosiasi dapat diartikan sebagai: Proses tawarmenawar dengan jalan berunding untuk memberi atau menerima guna mencapai kesepakatan bersama antara satu pihak (kelompok atau organisasi) dan pihak (kelompok atau organisasi yang lain); Penyelesaian sengketa secara damai melalui perundingan antara pihak-pihak yang bersengketa.

Perselisihan hubungan industrial wajib dilakukan penyelesaian terlebih dahulu melalui perundingan bipartit yaitu perundingan antara pengusaha dengan pekerja secara musyawarah untuk mencapai mufakat, dan proses perundingan melalui bipartit harus diselesaikan dalam waktu 30 (tiga puluh) hari kerja sejak tanggal dimulainya perundingan, dan apabila dalam jangka waktu 30 (tiga puluh) hari dimaksud salah satu pihak menolak untuk berunding atau telah dilakukan perundingan tetapi tidak mencapai kesepakatan maka perundingan bipartit dianggap gagal.

Tata cara penyelesaian secara bipartit diatur dalam Pasal 6 dan Pasal 7 Undang-Undang No. 2 Tahun 2004, yang pada pokoknya adalah sebagai berikut: Pertama, Perundingan untuk mencari penyelesaian secara musyawarah untuk mencapai mufakat yang dilakukan oleh para pihak dan harus dibuatkan risalah yang ditandatangani oleh para pihak, risalah dimaksud antara lain memuat: Nama lengkap dan alamat para pihak; Tanggal dan tempat perundingan; Pokok masalah atau alasan perselisihan; Pendapat para pihak; Kesimpulan atau hasil perundingan; dan Tanggal, serta tanda tangan para pihak yang melakukan perundingan. Kedua, Jika musyawarah yang dilakukan mencapai kesepakatan penyelesaian dibuat perjanjian bersama yang ditandatangani oleh para pihak. Ketiga, Perjanjian bersama tersebut bersifat mengikat dan menjadi hukum serta wajib dilaksanakan oleh para pihak. Keempat, Perjanjian bersama itu wajib didaftarkan oleh para pihak yang melakukan perjanjian pada PHI pada Pengadilan Negeri di wilayah para pihak mengadakan perjanjian bersama. Kelima, Apabila perjanjian bersama itu tidak dilaksanakan oleh salah satu pihak, pihak yang merasa dirugikan dapat mengajukan eksekusi kepada PHI pada Pengadilan

\footnotetext{
${ }^{8}$ Tim Pusat Bahasa Depdiknas, Kamus Bahasa Indonesia, Pusat Bahasa Departemen Pendidikan Nasional, Jakarta, 2008, h. 1000 .
}

Negeri di wilayah para pihak di wilayah perjanjian bersama didaftarkan untuk mendapatkan penetapan eksekusi. Keenam, Dalam hal pemohon eksekusi berdomisili di luar Pengadilan Negeri tempat pendaftaran perjanjian bersama, pemohon eksekusi dapat mengajukan permohonan eksekusi melalui PHI pada Pengadilan Negeri di wilayah domisili pemohon eksekusi untuk diteruskan ke PHI pada Pengadilan Negeri yang kompeten melaksanakan eksekusi.

Apabila perundingan bipartit tidak terdapat kesepakatan/gagal maka salah satu pihak yaitu pekerja atau pengusaha melaporkan kepada Dinas Tenaga Kerja (selanjutnya disingkat Disnaker) untuk mencatatkan bahwa perundingan bipartit antara pengusaha dan pekerja tidak dapat tercapai dengan melampirkan bukti-bukti bahwa upaya-upaya penyelesaian melalui perundingan bipartit telah dilakukan antara pengusaha dengan pekerja, dan apabila salah satu pihak tidak melampirkan buktibukti telah dilakukan upaya penyelesaian bipartit maka Disnaker mengembalikan pengaduan salah satu pihak untuk dilengkapi dalam waktu 7 (tujuh) hari kerja sejak tanggal diterimanya pengembalian berkas.

Adapun dalam proses penyelesaian secara Bipartit, berkas yang perlu dibuat adalah: Risalah Hasil Perundingan; Daftar hadir perundingan; Permintaan dan pemberitahuan perundingan dari salah satu pihak.

Disnaker setelah menerima pengaduan dari salah satu pihak lalu melakukan pencatatan dan menawarakan kepada salah satu pihak untuk menyepakati dengan surat pernyataan memilih penyelesaian melalui konsiliasi atau melalui arbitrase, dan apabila para pihak yaitu pihak pekerja atau pihak pengusaha tidak menetapkan pilihan penyelesaian sengketa baik melalui konsiliasi atau arbitrase maka dalam waktu 7 (tujuh) hari kerja, maka Disnaker melimpahkan penyelesaian perselisihan kepada mediator yang daftar nama mediator tercatat pada Disnaker untuk dilakukan proses mediasi.

Penyelesaian perselisihan hubungan industrial melalui konsiliasi merupakan salah satu alternatif penyelesaian perselisihan, upaya yang bersifat pilihan (voluntary), bukan hal yang wajib sebagaimana penyelesaian secara bipatrit maupun penyelesaian melalui mediasi. 
Konsiliasi hubungan industrial atau yang kemudian disebut konsiliasi adalah penyelesaian kepentingan, perselisihan pemutusan hubungan kerja, dan perselisihan antar serikat pekerja/serikat buruh hanya dalam satu perusahaan melalui musyawarah yang ditengahi oleh seorang atau lebih konsiliator yang netral, konsiliator yang ditetapkan oleh Menteri.

Tugas konsiliator melakukan konsiliasi dengan mengupayakan musyawarah untuk mencapai mufakat, bila dalam perundingan mencapai kesepakatan dituangkan dalam bentuk perjanjian bersama ditandatangani oleh kedua belah pihak dan disaksikan oleh konsiliator dan selanjutnya mendaftarkan perjanjian bersama tersebut pada PHI untuk memperoleh bukti pendaftaran, apabila perjanjian bersama yang disepakati dan sudah didaftarkan tersebut tidak dipatuhi oleh para pihak maka dapat mengajukan permohonan eksekusi kepada PHI.

Sebaliknya apabila konsiliasi tidak tercapai kesepakatan maka langkah yang dilakukan oleh konsiliator, adalah sebagai berikut: ${ }^{9}$ pertama, Konsiliator mengeluarkan anjuran tertulis; kedua, Dalam waktu selambat-lambatnya 10 (sepuluh) hari kerja sejak sidang konsiliasi pertama anjuran tertulis sudah disampaikan kepada para pihak; ketiga, Para pihak harus memberikan jawaban tertulis kepada konsiliator yang isinya menyetujui atau melakukan anjuran dalam waktu selambatlambatnya 10 (sepuluh) hari sejak menerima anjuran; keempat, Pihak yang tidak memberikan jawaban atau pendapatnya dianggap menolak anjuran; kelima, Terhadap anjuran konsiliator apabila para pihak menyetujui, maka dalam waktu selambat-lambatnya 3 (tiga) hari kerja sejak anjuran disetujui, konsiliator harus sudah selesai membantu para pihak membuat perjanjian bersama yang kemudian didaftarkan di PHI untuk mendapatkan bukti pendaftaran; keenam, Keseluruhan proses penyelesaian perselisihan hubungan industrial melalui konsiliasi dilaksanakan dalam kurun waktu selambat-lambatnya 30 (tiga) puluh hari kerja, terhitung sejak menerima permintaan penyelesaian perselisihan.

Konsiliator tersebut harus terdaftar pada kantor instansi yang bertanggungjawab di bidang ketenagakerjaan kabupaten/kota, Adapun persyaratan

\footnotetext{
${ }^{9}$ Pasal 23 ayat (2) Undang-Undang No. 2 Tahun 2004 tentang Penyelesaian Perselisihan Hubungan Industrial.
}

sebagai konsiliator, adalah sebagai berikut: Beriman dan bertaqwa kepada Tuhan Yang Maha Esa; Warga Negara Indonesia; Berumur sekurang-kurangnya 45 tahun; Pendidikan minimal lulusan Strata Satu (S1); Berbadan sehat menurut surat keterangan dokter; Berwibawa, jujur, adil dan berkelakuan tidak tersela; Memiliki pengalaman di bidang hubungan industrial sekurang-kurangnya 5 (lima) tahun; Menguasai peraturan perundang-undangan di bidang ketenagakerjaan; Syarat lain yang ditetapkan oleh Menteri.

Penyelesaian hubungan industrial melalui mediasi, kata mediasi berasal dari bahasa Inggris mediation, yang artinya penyelesaian sengketa yang melibatkan pihak ketiga sebagai penengah atau penyelesaian sengketa secara menengahi dan yang menengahinya disebut mediator atau orang yang menjadi penengah. ${ }^{10}$ Dalam terminologi hukum, istilah mediation berarti pihak ketiga yang ikut campur perkara cenderung mencari penyelesaiannya. ${ }^{11}$

Untuk memberikan gambaran yang lebih jelas mengenai mediasi, berikut diuraikan pengertian mediasi, menurut pendapat para sarjana, adalah sebagai berikut:

Pertama, Mediation is generally defined as the intervention in a negotiation or a conflict of an acceptable third party who has limited or no authoritative discision making power but who assits the involved parties in voluntarily reaching a mutually acceptable settlement of issues in dispute. ${ }^{12}$

Kedua, Leonard L. Riskin dan James E. Westbrook menyatakan mediation is an informal process in which a neutral third party helps other resolve a dispute or plan atransaction but does not (and ordinarily does not have the power to impose asolution). ${ }^{13}$

Ketiga, Christopher W. Moore menyatakan, mediasi adalah intervensi dalam sebuah sengketa atau negosiasi oleh pihak ketiga yang bisa diterima

${ }^{10}$ I.P.M. Danuhandoko, Terminologi Hukum InggrisIndonesia, Cetakan Keempat, Sinar Grafika, Jakarta, 2006, h. 399.

${ }^{11}$ Ibid.

${ }^{12}$ Cristopher W. More (selanjutnya disebut Cristopher W. More I), The Mediation Prosess Practical Strategies for Resolving Conflict, Second Edition, Jossy Bas, San Francisco, 1996, h. 15.

${ }^{13}$ Leonard L. Riskin dan James E. Westbrook, Dispute Resolution and Lawyers, West Publishing, St. Paul, 1987, h. 96. 
pihak yang bersengketa, bukan merupakan bagian dari kedua belah pihak dan bersifat netral. Pihak ketiga ini tidak mempunyai wewenang untuk mengambil keputusan. Dia bertugas untuk membantu pihak-pihak yang bertikai agar secara sukarela mau mencapai kata sepakat yang diterima oleh masingmasing pihak dalam sebuah persengketaan. ${ }^{14}$

Keempat, Mark E. Roszkowski mengemukakan bahwa mediation is a relatively informalprocess in which a neutral third party, the mediator, helps to resolve a dispute. In many respect, therefore, mediator can be considered as structured negotiation in which the mediator facilitates the process. ${ }^{15}$

Kelima, John W. Head, mengatakan mediasi adalah suatu prosedur penengahan di mana seorang bertindak sebagai kendaraan untuk berkomunikasi antar para pihak, sehingga pandangan mereka yang berbeda atas sengketa tersebut dapat dipahami dan mungkin didamaikan, tetapi tanggung jawab utama tercapainya suatu perdamaian tetap berada di tangan para pihak sendiri. ${ }^{16}$

Keenam, Jay Folberg dan Richard Holderness Sorton Jones, mengatakan mediasi merupakan salah satu bentuk ADR yang merupakan bentuk negosiasi dari para pihak yang bersengketa mengenai sengketa

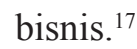

Ketujuh, Mediation is a short term structure task oriented, parcipatory invention process. Disputing parties work with a neutral third party, the mediator, to reach amutually acceptable agreement. ${ }^{18}$

${ }^{14}$ Cristopher W. More (selanjutnya disebut Cristopher W. More II), Mediasi Lingkungan, Indonesia Center for Environmental Law and CDR Associates, Jakarta, 1995, h. 18.

${ }^{15}$ Mark E. Roszkowki, Business Law Principle Cases and Policy, Addison Welwy Longman Inc., United States, 1997, dalam Gunawan Widjaya dan Ahmad Yani, Seri Hukum Bisnis: Hukum Abitrase, Raja Grafindo Persada, Jakarta, 2000, h. 33.

${ }^{16}$ John W. Head, Pengantar Umum Hukum Ekonomi, Proyek ELIPS, Jakarta, 1997, h. 24.

${ }^{17}$ Gary Goodpaster, Tinjauan terhadap Penyelesaian Sengketa, Ghalia Indonesia, Jakarta, 1995, dalam Felix O. Soebagjo (ed.), Arbitrase di Indonesia, Seri Dasar-Dasar Hukum Ekonomi 2, Ghalia Indonesia, Jakarta, 1995, h. 11.

${ }^{18}$ Nolan Halley, Alternative Dispute Resolution, West Publishing, St. Paul, 1992, dalam Surya Perdana, Disertasi, "Mediasi Merupakan Salah Satu Cara Penyelesaian Perselisihan Pemutusan Hubungan Kerja pada Perusahaan di Sumatera Utara", Program Pascasarjana Universitas Sumatera Utara, Medan, 2008, h. 62 .
Kedelapan, Mediasi adalah jasa-jasa baik, mediasi, perantaraan di dalam pergaulan hukum antara bangsa. Jasa-jasa baik tidak mengikat. ${ }^{19}$

Kesembilan, Mediasi pada dasarnya merupakan negosiasi yang mengikutsertakan pihak ketiga yang ahli dalam cara-cara negosiasi yang efektif dan dapat membantu para pihak dalam sengketa dengan mengkoordinasikan kegiatan-kegiatan, dan agar lebih efektif dalam bernegosiasi. ${ }^{20}$

Dalam Undang-Undang No. 30 Tahun 1999 tentang Arbitrase dan Alternatif Penyelesaian Sengketa, tidak diketemukan pengertian mediasi dengan jelas, namun apabila diperhatikan pengertian mediasi ini terdapat dalam Pasal 6 ayat (3) yang menyebutkan, bahwa atas kesepakatan tertulis para pihak, sengketa atau beda pendapat diselesaikan melalui bantuan seorang atau lebih penasehat ahli maupun melalui seorang atau lebih mediator.

Berdasarkan Pasal 1 angka 1 Peraturan Mahkamah Agung RI No. 1 Tahun 20016 tentang Prosedur Mediasi di Pengadilan, menyebutkan Mediasi adalah cara penyelesaian sengketa melalui proses perundingan untuk memperoleh kesepakatan para pihak dengan dibantu oleh Mediator.

Keputusan yang diambil dalam penyelesaian sengketa melalui mediasi didasarkan atas kehendak para pihak yang bersengketa, jadi bukan atas kehendak pihak ketiga (mediator). Mediator tersebut tetap bersikap netral dan selalu membina hubungan baik dengan kedua belah pihak, berbicara dengan bahasa para pihak, mendengarkan secara aktif, memberikan saran-saran, menekankan pada keuntungan potensial serta meminimalisir perbedaan-perbedaan dengan menitikberatkannya pada persamaan. Oleh sebab itu, tujuan mediasi adalah untuk membantu para pihak bernegosiasi secara lebih baik terhadap penyelesaian suatu sengketa. ${ }^{21}$

Pertama, Unsur-unsur mengenai pengertian mediasi, sebagai berikut: 1 . Mediasi adalah sebuah proses penyelesaian sengketa berdasarkan pada perundingan; 2. Mediator dapat diterima dan pilihan para pihak yang bersengketa untuk menfasilitasi proses perundingan; 3 . Mediator bertugas membantu

\footnotetext{
${ }^{19}$ Mr. N.E. Algra, et.al., Kamus Istilah Hukum Fockema Andreae Belanda-Indonesia, Bina Cipta, Bandung, 1983, h. 293.

${ }^{20}$ Christopher W. More, The Mediation Prosess dalam Pengantar Mediasi, Pusat Mediasi Nasional, Jakarta, 2012, h. 2.

21 Surya Perdana, Loc. Cit., h. 64.
} 
para pihak yang bersengketa untuk mencari solusi penyelesaian sengketa; 4 . Mediator tidak mempunyai kewenangan untuk membuat keputusan selama proses perundingan berlangsung; 5. Tujuan Mediasi adalah untuk mencapai atau menghasilkan kesepakatan yang dapat diterima oleh pihak-pihak yang bersengketa guna mengakhiri sengketanya.

Kedua, Asas-asas yang digunakan dalam proses mediasi, yaitu: Asas-asas Hukum Mediasi, Asas yang dalam bahasa Inggris disebut principle yang dapat berarti sebagai: a. sumber atau asal sesuatu, $b$. penyebab yang jauh dari sesuatu, $c$. kewenangan atau kecakapan asli, d. aturan atau dasar bagi tindakan seseorang, dan e. suatu pernyataan (hukum, aturan, kebenaran) yang dipergunakan sebagai dasar-dasar untuk menjelaskan sesuatu peristiwa. ${ }^{22}$

Satjipto Rahardjo, berpendapat bahwa asas hukum merupakan jantungnya peraturan hukum, disebut demikian karena asas hukum merupakan landasan yang paling luas bagi lahirnya peraturan hukum, yang pada akhirnya peraturan-peraturan hukum itu akan kembali kepada asas-asas tersebut. Artinya asas hukum ini dapat disebut sebagai alasan lahirnya peraturan hukum, atau merupakan ratio legis dari peraturan hukum. ${ }^{23}$

Didasarkan peraturan perundang-undangan, dapat dicermati terdapat beberapa asas dalam penyelesaian sengketa melalui mediasi:

Pertama, Asas kesukarelaan para pihak. Bahwa dalam melakukan proses mediasi para pihak yaitu pihak pengusaha dan pihak pekerja diberikan kebebasan untuk memilih penyelesaikan perselisihannya melalui mediasi karena mereka yakin dengan memilih penyelesaian melalui proses mediasi diharapkan akan membawa kebaikan semua pihak sehingga tidak ada keterpaksaan dalam menyelesaikan perselisihannya melalui mediasi.

Kedua, Asas musyawarah. Asas musyawarah ini merupakan tindakan bersama antara para pihak yang bersengketa untuk mengambil suatu pendapat bersama yang bulat atas permasalahan yang dihadapi para pihak. Dalam penyelesaian sengketa melalui mediasi asas musyawarah merupakan hal yang mendasar dalam setiap pengambilan

\footnotetext{
22 Mahadi, Falsafah Hukum Suatu Pengantar, Alumni, Bandung, 1991, h. 119.

${ }^{23}$ Satjipto Rahardjo, Ilmu Hukum, Alumni, Bandung, 1986, h. 85 .
}

keputusan. Masing-masing para pihak yang bersengketa diberikan hak yang seluas-luasnya untuk menyampaikan apa yang ia rasakan dan mengharapkan apa yang ia inginkan kepada pihak lain melalui perantara mediator. Para pihak dalam penyelesaian sengketa ini tidak mengenal adanya intimidasi, paksaan maupun tekanan dari pihak manapun, dan yang paling penting adalah diharapkan para pihak saling menerima dan bersedia mengalah untuk mencapai suatu kesepakatan bersama. ${ }^{24}$

Ketiga, Asas mufakat. Asas ini mengajarkan bahwa perbedaan-perbedaan kepentingan pribadi di antara para pihak yang bersengketa haruslah diselesaikan dengan cara perundingan, antara seorang dengan orang lain yang bersengketa. Perundingan ditujukan kepada pihak-pihak yang bersengketa akibat terjadinya perbedaan antara kehendak atau prinsip dan pendirian dari masing-masing pihak. Dengan melakukan tawar-menawar keinginan diharapkan sampai pada persamaan dan kesepakatan mengenai apa yang dikehendaki oleh masing-masing pihak. Dalam mewujudkan proses tawar-menawar tersebut masing-masing pihak harus saling bersikap menerima dan memberi dengan ikhlas hati untuk sampai kepada persamaan kehendak bersama. Asas ini sangat berperan dan tampak jelas dalam penyelesaian sengketa melalui mediasi, di mana setiap keputusan yang diambil dalam proses mediasi merupakan hasil dari proses tawar-menawar yang kesemuanya dilakukan melalui kesepakatan dalam perundingan. Artinya para pihak yang bersengketa tidak ada yang tetap mempertahankan haknya secara absolut, hal ini tidak lain untuk mencapai kesepakatan bersama antara para pihak dalam mengemukakan pendapat dan keinginannya. Kesepakatan untuk mengambil keputusan harus dilakukan dengan bebas tanpa ada paksaan dan tekanan dalam bentuk apapun dan dari siapapun, sehingga kesepakatan bersama yang dicapai melalui mediasi merupakan kesepakatan yang benar-benar bersumber dari hati nurani yang dalam dari masing-masing pihak yang bersengketa. Untuk itu, peran mediator harus betul-betul netral, hanya berusaha semaksimal mungkin dalam membantu,

\footnotetext{
${ }^{24}$ Moh. Koesnoe, Catatan-Catatan terhadap Hukum Adat Dewasa Ini, Airlangga University Pers, Surabaya, dalam Surya Perdana, Op.Cit., h. 67.
} 
membimbing dan mengarahkan para pihak yang bersengketa untuk mencapai konsensus bersama. ${ }^{25}$

Keempat, Asas Kepatutan. Asas kepatutan ini merupakan asas yang mengarah kepada usaha untuk mengurangi jatuhnya perasaan seseorang karena rasa malu yang ditimbulkan oleh hasil penyelesaian sengketa tersebut. Oleh karena itu, asas kepatutan ini memusatkan perhatiannya kepada cara menemukan penyelesaian sengketa yang dapat menyelamatkan kualitas dan status pihak-pihak yang bersangkutan dengan sebaik-baiknya. Penyelesaian sengketa melalui mediasi akan menyelamatkan harkat dan martabat para pihak yang bersengketa dengan lebih baik, hal ini dikarenakan tidak ada para pihak yang dikalahkan dan dimenangkan oleh keputusan mediasi. Keputusan mediasi semata-mata merupakan hasil kesepakatan para pihak, yang merupakan solusi terbaik untuk menghindarkan para pihak dari rasa malu di tengah-tengah masyarakat. ${ }^{26}$

Penyelesaian perselisihan hubungan industrial melalui Mediasi dilakukan oleh mediator yang terdaftar pada Dinas Tenaga kerja, sedangkan pengertian mediator hubungan industrial yang selanjutnya disebut Mediator adalah pegawai instansi pemerintah yang bertanggungjawab di bidang ketenagakerjaan yang memenuhi syarat-syarat sebagai Mediator yang ditetapkan oleh Menteri Tenaga Kerja dan Transmigrasi untuk bertugas melakukan mediasi dan mempunyai kewajiban memberikan anjuran tertulis kepada para pihak yang berselisih untuk menyelesaikan perselisihan hak, perselisihan kepentingan, perselisihan pemutusan hubungan kerja, dan perselisihan antar serikat pekerja/serikat buruh hanya dalam satu perusahaan.

Syarat-syarat sebagai mediator, adalah sebagai berikut: ${ }^{27}$ Beriman dan bertaqwa kepada Tuhan Yang Maha Esa; Warga Negara Indonesia; Pegawai negeri sipil pada instansi yang bertanggungjawab di bidang ketenagakerjaan; Berbadan sehat menurut surat keterangan dokter; Menguasai peraturan

${ }^{25}$ Ibid., h. 68.

${ }^{26}$ Runtung, "Keberhasilan dan Kegagalan Penyelesaian Sengketa Alternatif (Studi Mengenai Masyarakat Karo di Kabanjahe dan Berastagi)", Disertasi, Program Pascasarjana Universitas Sumatera Utara, Medan, 2002, h. 198.

${ }^{27}$ Pasal 2 ayat (1) Peraturan Menteri Tenaga Kerja dan Transmigrasi RI No. 17 Tahun 2014 tentang Pengangkatan dan Pemberhentian Mediator Hubungan Industrial serta Tatakerja Mediasi. perundang-undangan di bidang ketenagakerjaan; Berwibawa, jujur, adil dan berkelakuan tidak tercela; Berpendidikan sekurang-kurangnya Strata Satu (S1); Memiliki sertifikat kompetensi; dan memiliki surat keputusan pengangkatan dari Menteri.

Untuk memperoleh surat keputusan pengangkatan dari Menteri Tenaga Kerja dan transmigrasi, harus memenuhi syarat-syarat: telah mengikuti dan lulus pendidikan dan pelatihan Mediator yang dibuktikan dengan sertifikat dari Kementerian; dan telah melaksanakan tugas di bidang hubungan industrial sekurang-kurangnya 1 (satu) tahun atau ikut mendampingi dalam pembinaan dan penyelesaian Perselisihan Hubungan Industrial paling sedikit 10 (sepuluh) kasus.

Setelah menerima pelimpahan berkas pengaduan adanya perselisihan mediator selambat-lambatnya dalam waktu 7 (tujuh) hari harus sudah mengadakan penelitian tentang duduk perkara yang diperselisihkan dan sesegera mungkin memanggil pihak pekerja dan pihak pengusaha untuk dilakukan proses mediasi.

Berdasarkan Pasal 9 Peraturan Menteri Tenaga Kerja dan Transmigrasi No. 17 Tahun 2014 tentang Pengangkatan dan Pemberhentian Mediator Hubungan Industrial serta Tata Kerja Mediator, maka seorang mediator untuk memperlancar penyelesaian perselisihan memiliki kewajiban: meminta kepada para pihak untuk berunding sebelum dilaksanakan proses Mediasi; memanggil para pihak yang berselisih; memimpin dan mengatur jalannya sidang Mediasi; membantu para pihak membuat perjanjian bersama, apabila tercapai kesepakatan; membuat anjuran secara tertulis, apabila tidak tercapai kesepakatan; membuat risalah penyelesaian Perselisihan Hubungan Industrial; menjaga kerahasiaan semua keterangan yang diperoleh; membuat laporan hasil penyelesaian Perselisihan Hubungan Industrial kepada Direktur Jenderal atau Kepala Dinas Propinsi atau Kepala Dinas Kabupaten/ Kota yang bersangkutan; dan mencatat hasil penyelesaian Perselisihan Hubungan Industrial dalam buku registrasi Perselisihan Hubungan Industrial.

Disamping Peraturan Menteri Tenaga Kerja dan Transmigrasi No. 17 Tahun 2014 tentang Pengangkatan dan Pemberhentian Mediator Hubungan Industrial serta Tata Kerja Mediator, tersebut mediator dapat memanggil saksi atau ahli untuk hadir dalam proses mediasi guna diminta 
dan didengar keterangannya, serta dapat meminta keterangan, dokumen dan surat-surat yang berkaitan dengan perselisihan kepada para pihak.

Dalam proses mediasi agar tercapai kesepakatan yang dikehendaki para pihak sebenarnya tidak terlepas dari peran seorang atau beberapa orang mediator, menurut Menurut Christopher W. Moore ${ }^{28}$ proses mediasi yang harus dilakukan oleh mediator adalah: pertama, Perkenalkan diri sendiri sebagai mediator; kedua, Ucapkan selamat datang kepada semua pihak dan perkokoh kesediaan mereka untuk membahas masalah atau menegosiasikan penyelesaian masalah; ketiga, Ulas kembali alasan mengapa pihak-pihak terlibat harus datang berkumpul dengan penjelasan yang bersifat netral; keempat, Jelaskan bahwa proses mediasi adalah: 1. Suatu upaya oleh pihak-pihak yang bersengketa untuk mencapai kesepakatan mereka sendiri melalui diskusi atau negosiasi; 2. Bersifat sukarela, tanpa paksaan; kelima, Jelaskan peran anda: 1. Sebagai pihak netral/tidak memihak siapapun; 2. Sebagai pembantu untuk memperlancar proses. bahwa anda bukanlah seorang pembuat keputusan; keenam, Jelaskan proses pemecahan masalah: 1. Setiap orang akan berbicara dan menjelaskan situasi; 2. Para peserta negosiasi akan melakukan kesepakatan terhadap topik-topik tertentu untuk pembahasan; 3. Para peserta akan membuat agenda; 4. Para peserta akan saling menjelaskan kepada semua pihak mengenai kepentingan dan kebutuhan mereka; 5. Para peserta akan mendiskusikan butir-butir agenda satu persatu; 6. Para perserta akan mencari pemecahan masalah yang memuaskan semua pihak; 7. Kesepakatan ditulis dan diformalisasikan menurut keinginan para pihak bersengketa; ketujuh, Jelaskan batas-batas kerahasiaan, seperti ancaman-ancaman fisik yang akan segera terjadi atau kejadian yang sedang terjadi, dalam bentuk kerugian fisik terhadap para negosiator atau pihak yang berhubungan dengan negosiator; kedelapan, Jelaskan proses dan keinginan untuk mendapatkan bimbingan hukum dan peninjauan ulang sebelum, selama dan pada akhir negosiasi; kesembilan, Jelaskan kegunaan pertemuanpertemuan tertutup; kesepuluh, Identifikasi dengan pihak-pihak terlibat, panduan prosedural yang bisa membantu mereka untuk bernegosiasi dengan cara yang efektif; kesebelas, Mintalah peserta untuk

\footnotetext{
${ }^{28}$ Rachmadi Usman, Pilihan Penyelesaian Sengketa di Luar Pengadilan, Citra Aditya Bakti, Bandung, 2003, h. 100-103.
}

mengajukan pertanyaan dan jawablah pertanyaan yang ditanyakan oleh pihak-pihak yang bersengketa; keduabelas, Dapatkan komitmen masing-masing dari tiap pihak untuk memulai negosiasi, baik secara lisan ataupun tertulis.

Selanjutnya menurut Gary Goodpaster ${ }^{29}$ membagi proses pelaksanaan mediasi berlangsung melalui 4 (empat) tahap, yaitu:

Pertama, Menciptakan forum, dalam tahap pertama ini kegiatan-kegiatan yang dilakukan mediator adalah: 1. Mengadakan pertemuan bersama; 2. Pernyataan pembukaan mediator; 3 . Membimbing para pihak; 4. Menetapkan aturan dasar perundingan; 5. Mengembangkan hubungan dan kepercayaan di antara para pihak; 6. Pernyataan-pernyataan para pihak; 7. Para pihak mengadakan atau melakukan hearing dengan mediator; 8. Mengembangkan, menyampaikan dan melakukan klarifikasi informasi; 9. Menciptakan interaksi model dan disiplin.

Kedua, Pengumpulan dan pembangian informasi, dalam tahap kedua ini mediator akan mengadakan pertemuan-pertemuan secara terpisah atau caucuscaucus guna: 1. Mengembangkan informasi lanjutan; 2. Melakukan eksplorasi yang mendalam mengenai keinginan atau kepentingan para pihak; 3. Membantu para pihak dalam menaksir dan menilai kepentingan. 4. Membimbing para pihak dalam tawar-menawar penyelesaian masalah.

Ketiga, Penyelesaian masalah, dalam tahap ketiga ini mediator dapat mengadakan pertemuan bersama atau caucus-caucus terpisah sebagai tambahan atau kelanjutan dari pertemuan sebelumnya, dengan maksud untuk: 1. Menyusun dan menetapkan agenda; 2. Merumuskan kegiatan-kegiatan penyelesaian masalah; 3. Meningkatkan kerjasama; 4. Melakukan identifikasi dan klarifikasi masalah; 5. Mengadakan pilihan penyelesaian masalah; 6. Membantu melakukan pilihan penaksiran; 7. Membantu para pihak dalam menaksir, menilai dan membuat prioritas kepentingan-kepentingan mereka.

Keempat, Pengambilan keputusan, dalam tahap keempat ini dalam rangka pengambilan keputusan kegiatan-kegiatan yang mesti dilakukan: 1. Mengadakan caucus-caucus dan pertemuanpertemuan bersama; 2. Melokasikan peraturan, mengambil sikap dan membantu para pihak mengevaluasi paket-paket pemecahan masalah; 3 .

\footnotetext{
${ }^{29}$ Surya Perdana, Op.Cit., h. 197.
} 
Membantu para pihak untuk memperkecil perbedaanperbedaan; 4. Mengkonfirmasi dan mengklarifikasi perjanjian; 5. Membantu para pihak untuk membandingkan proposal penyelesaian masalah dengan pilihan di luar perjanjian; 6. Mendorong atau mendesak para pihak untuk menghasilkan menerima pemecahan masalah; 7. Memikirkan formula pemecahan masalah yang win-win dan tidak hilang muka; 8. Membantu para pihak melakukan mufakat dengan pemberi kuasa mereka; 9. Membantu para pihak membuat pertanda perjanjian.

Tata kerja mediasi dalam menyelesaikan perselisihan sebagai diatur dalam Peraturan Menteri Tenaga Kerja dan Transmigrasi No. 17 Tahun 2014 tentang Pengangkatan dan Pemberhentian Mediator Hubungan Industrial serta Tata Kerja Mediator, mengatur pada pokoknya sebagai berikut:

Pertama, Mediator setelah menerima pelimpahan berkas perselisihan, maka ia harus: 1 . Melakukan penelitian berkas perselisihan; 2. Melakukan sidang mediasi paling lambat 7 (tujuh) hari kerja setelah menerima pelimpahan tugas untuk menyelesaikan perselisihan; 3. Memanggil para pihak secara tertulis untuk menghadiri sidang dengan mempertimbangkan waktu panggilan sehingga sidang mediasi dapat dilaksanakan selambat-lambatnya 7 (tujuh) hari kerja sejak menerima pelimpahan tugas untuk menyelesaikan perselisihan; 4. Melaksanakan sidang mediasi dengan mengupayakan penyelesaian secara musyawarah untuk mufakat; 5. Mengeluarkan anjuran secara tertulis kepada para pihak apabila penyelesaian tidak mencapai kesepakatan; 6. Membantu membuat perjanjian bersama secara tertulis apabila tercapai kesepakatan penyelesaian, yang ditandatangani oleh para pihak dan disaksikan oleh mediator; 7. Memberi tahu para pihak untuk mendaftarkan perjanjian bersama yang telah ditandatangani para pihak ke PHI pada Pengadilan Negeri tempat di mana perjanjian bersama ditandatangani untuk mendapatkan akta bukti pendaftaran; 8 . Membuat risalah pada setiap penyelesaian perselisihan hubungan industrial.

Kedua, Dalam hal salah satu pihak atau para pihak menggunakan jasa kuasa hukum dalam sidang mediasi, maka pihak yang menggunakan jasa kuasa hukum tersebut harus tetap hadir.

Ketiga, Dalam hal para pihak telah dipanggil dengan mempertimbangkan waktu penyelesaian ternyata pihak pemohon tidak hadir, maka permohonan tersebut dihapus dari buku perselisihan.

Keempat, Apabila para pihak telah dipanggil dengan mempertimbangkan waktu penyelesaian ternyata pihak termohon tidak hadir, maka mediator mengeluarkan anjuran tertulis berdasarkan data-data yang ada.

Kelima, Apabila para pihak tidak menjawab anjuran secara tertulis maka para pihak dianggap menolak anjuran, mediator mencatat dalam buku perselisihan bahwa perselisihan tidak dapat diselesaikan melalui mediasi dan melaporkan kepada pejabat yang memberi penugasan.

Keenam, Dalam hal para pihak menyetujui anjuran dan menyatakan secara tertulis, maka mediator membantu membuat perjanjian bersama secara tertulis selambat-lambatnya 3 (tiga) hari kerja sejak anjuran disetujui para pihak yang kemudian ditandatangani oleh para pihak dan mediator sebagai saksi. Anjuran tertulis mediator memuat: Keterangan pekerja atau keterangan serikat pekerja; Keterangan pengusaha; Keterangan saksi dan saksi ahli apabila ada; Pertimbangan hukum dan kesimpulan mediator; Isi anjuran.

Ketujuh, Apabila mediator mengeluarkan anjuran dengan mempertimbangkan keterangan yang harus dirahasiakan menurut permintaan pemberi keterangan, maka dalam anjuran mediator cukup menyatakan kesimpulan berdasarkan keterangan yang harus dirahasiakan dalam pertimbangannya.

Mediator untuk menyelesaikan proses mediasi dibatasi dengan waktu yaitu selambat-lambatnya 30 (tiga puluh) hari kerja terhitung sejak mediator menerima pelimpahan penyelesaian perselisihan. Apabila dalam proses mediasi kedua belah pihak telah tercapai kesepakatan penyelesaian perselisihan hubungan industrial melalui mediasi, maka dibuat perjanjian bersama yang ditandatangani oleh para pihak dan disaksikan oleh mediator serta kemudian didaftarkan di PHI pada Pengadilan Negeri di wilayah hukum para pihak yang mengadakan perjanjian untuk mendapatkan akta bukti pendaftaran guna mendapatkan kepastian hukum apabila tidak dilaksanakan oleh kedua belah pihak maka pihak yang dirugikan dapat mengajukan permohonan eksekusi kepada PHI di mana perjanjian tersebut didaftarkan. 
Apabila penyelesaian perselisihan hubungan industrial melalui mediasi tidak tercapai, maka: Pertama, Mediator mengeluarkan risalah/anjuran tertulis, adapun isi risalah/anjuran memuat: keterangan pekerja atau keterangan serikat pekerja/serikat buruh; keterangan pengusaha; keterangan saksi/saksi ahli apabila ada; pendapat dan pertimbangan hukum; dan isi anjuran. Kedua, Anjuran tertulis tersebut selambat-lambatnya 10 (sepuluh) hari kerja sejak sidang mediasi pertama harus sudah disampaikan kepada para pihak. Ketiga, Para pihak harus sudah memberikan jawaban secara tertulis kepada mediator yang isinya menyetujui atau menolak anjuran tertulis dalam waktu selambat-lambatnya 10 (sepuluh) hari kerja setelah menerima anjuran tertulis. Keempat, Pihak yang tidak memberikan pendapatnya dianggap menolak anjuran tertulis. Kelima, Apabila anjuran tertulis ditolak oleh salah satu pihak atau para pihak, maka para pihak atau salah satu pihak dapat melanjutkan penyelesaian perselisihan ke PHI pada Pengadilan Negeri di mana Tergugat bekerja.

Bahwa tahapan mediasi wajib dilakukan dalam proses perselisihan hubungan industrial karena dalam pengajuan gugatan ke PHI wajib dilampiri risalah/ anjuran penyelesaian melalui mediasi atau konsiliasi.

\section{Pengajuan Gugatan pada Pengadilan Hubungan Industrial}

Pengajuan gugatan dapat diajukan kepada PHI pada Pengadilan Negeri yang daerah hukumnya meliputi tempat pekerja bekerja. Pengajuan gugutan wajib dilampiri risalah/anjuran penyelesaian melalui mediasi maupun konsiliasi. Bila gugatan tidak dilampiri risalah penyelesaian tersebut, PHI wajib mengembalikan gugatan tersebut kepada penggugat.

Setelah dibuat gugatan memenuhi syarat formil maupun syarat materiil gugatan diajukan pada PHI, dalam hal suatu perselisihan melibatkan lebih dari satu penggugat dapat diajukan dengan cara kolektif dengan memberikan kuasa khusus kepada Serikat pekerja/serikat buruh dan organisasi pengusaha bagi anggota serikat pengusaha, karena serikat pekerja atau organisasi pengusaha dapat bertindak sebagai kuasa hukum untuk dapat beracara di PHI untuk mewakili anggotanya. Hakim yang menerima pengajuan gugatan wajib memeriksa isi gugatan dan bila terdapat kekurangan hakim meminta penggugat untuk melengkapi dan menyempurnakan gugatannya. Dalam penyempurnaan gugatan ini, panitera atau panitera pengganti dapat membantu penyusunan atau penyempurnaan gugatan. Untuk itu panitera atau panitera pengganti mencatat dalam daftar khusus memuat: a. Nama lengkap dan alamat atau tempat kedudukan para pihak; b. Pokok-pokok yang menjadi perselisihan atau obyek gugatan; c. Dokumen-dokumen, surat-surat, dan hal-hal lain yang dianggap perlu oleh penggugat..$^{30}$

Penggugat dalam sewaktu-waktu dapat mencabut gugatannya sebelum tergugat memberikan jawaban. Kemudian apabila tergugat sudah memberikan jawaban, pencabutan gugatan oleh penggugat akan dikabulkan oleh PHI apabila disetujui tergugat.

Ketua pengadilan dalam waktu selambatlambatnya tujuh hari kerja setelah menerima gugatan harus sudah menetapkan majelis hakim yang terdiri atas satu orang hakim sebagai ketua majelis dan dua orang hakim Ad-Hoc sebagai anggota majelis. Hakim Ad-Hoc ini terdiri dari seorang hakim Ad-Hoc yang pengangkatannya diusulkan oleh serikat pekerja/ serikat buruh dan seorang hakim Ad-Hoc yang pengangkatannya diusulkan oleh asosiasi pengusaha.

Dalam menyusun surat gugatan terdapat hal yang penting yang harus diperhatikan adalah masalah kewenangan absolut dan kewenangan relatif PHI. Jenis-jenis perselihan hubungan industrial yang menjadi kewenangan PHI adalah pemeriksaan dengan acara biasa dan pemeriksaan dengan acara cepat.

Pemeriksaan acara biasa mempunyai karakteristik dalam waktu selambat-lambatnya tujuh hari kerja sejak penetapan hakim, ketua majelis hakim harus sudah melakukan sidang pertama, yang ketentuannya sebagai berikut: ${ }^{31}$

Pertama, Pemanggilan para pihak ke sidang pengadilan harus dilakukan secara sah dengan menyampaikan surat kepada para pihak di alamat tempat tinggalnya atau apabila tempat tinggalnya tidak diketahui disampaikan di tempat kediamannya yang terakhir.

Kedua, Apabila pihak yang dipanggil tidak ada di tempat tinggalnya atau di tempat kediamannya yang terakhir, surat panggilan disampaikan melalui Kepala

\footnotetext{
30 Zaeni Asyhadie, Peradilan Hubungan Industrial, Raja Grafindo Persada, Jakarta, 2009, h. 132.

${ }^{31}$ Ibid., h. 133.
} 
Kelurahan atau Kepala Desa yang daerah hukumnya meliputi daerah tempat kediamannya yang terakhir.

Ketiga, Apabila tempat tinggalnya atau tempat kediamannya yang terakhir tidak dikenal, maka surat panggilan ditempelkan pada tempat pengumuman di gedung PHI.

Keempat, Majelis hakim dapat memanggil saksi atau ahli untuk hadir di persidangan guna diminta keteranganya oleh majelis hakim guna penyelidikan dan penyelesaian perselisihan hubungan industrial, wajib memberikan keterangan tanpa syarat, termasuk membukakan buku atau surat-surat yang diperlukan.

Kelima, Dalam hal salah satu pihak atau para pihak tidak dapat menghadiri sidang tanpa alasan yang dapat dipertanggungjawabkan, ketua majelis hakim menetapkan hari sidang berikutnya dalam waktu selambat-lambatnya tujuh hari sejak penundaan.

Keenam, Penundaan sidang karena ketidakhadiran salah satu pihak atau para pihak hanya dapat dilakukan dua kali.

Ketujuh, Dalam hal penggugat atau kuasa hukumnya yang dipanggil secara patut tidak datang menghadap pengadilan pada sidang penundaan terakhir, maka gugatannya dianggap gugur dan penggugat dapat mengajukan gugatan sekali lagi, sebaliknya.

Kedelapan, Tergugat atau kuasa hukumnya yang sah dipanggil secara patut tidak datang menghadap pengadilan pada sidang penundaan terakhir, maka majelis hakim dapat memeriksa dan memutus perselisihan tanpa dihadiri tergugat atau dengan putusan verstek.

Pemeriksaan dengan acara cepat mempunyai karakteristik apabila terdapat kepentingan para pihak atau salah satu pihak yang cukup mendesak yang dapat disimpulkan dari alasan-alasan permohonan dari yang berkepentingan, para pihak atau salah satu pihak dari mereka dapat mengajukan permohonan kepada PHI agar pemeriksaan penyelesaian sengketa dipercepat. Ketua Pengadilan yang menerima permohonan tersebut, harus dalam waktu paling lambat tujuh hari segera mengeluarkan penetapan apakah permohonan pemeriksaan dipercepat tersebut dikabulkan atau tidak. Dalam hal permohonan pemeriksaan sengketa secara cepat dikabulkan, maka Ketua Pengadilan Negeri dalam jangka waktu tujuh hari sejak permohonan pemeriksaan secara cepat dikabulkan, diwajibkan segera menetapkan majelis hakim, hari, tempat, dan waktu sidang tanpa melalui prosedur pemeriksaan.

\section{Pembuktian dalam Pengadilan Hubungan Industrial}

Pembuktian merupakan proses yang sangat penting dalam persidangan, untuk mengetahui kebenaran hal-hal yang dikemukan oleh para pihak dalam persidangan. Kebenaran dari suatu peristiwa ini hanya dapat diperoleh melalui pembuktian. Untuk dapat menjatuhkan putusan yang adil, hakim harus mengenal peristiwa yang telah dibuktikan kebenarannya. Dalam beberapa hal peristiwanya tidak perlu dibuktikan oleh hakim misalnya: ${ }^{32}$

Pertama, Dalam hal dijatuhkanya putusan verstek karena tergugat tidak datang meskipun sudah dipanggil secara patut. Dalam hal ini peristiwa yang menjadi sengketa yang dimuat dalam gugatan tanpa diadakannya pembuktian dianggap benar tanpa mendengar serta di luar hadirnya pihak tergugat dijatuhkan putusan verstek oleh hakim.

Kedua, Jika tergugat mengakui gugatan penggugat, peristiwa yang menjadi sengketa yang diakui tersebut dianggap telah terbukti, karena pengakuan merupakan alat bukti sehingga tidak memerlukan pembuktian lebih lanjut.

Ketiga, Telah dilakukannya sumpah decisoir, sumpah bersifat menentukan, peristiwa yang menjadi sengketa yang dimintakan sumpah dianggap terbukti dan tidak memerlukan pembuktian lebih lanjut.

Keempat, Secara ex officio hakim dianggap mengenal peristiwanya, sehingga tidak perlu dibuktikan lebih lanjut. Misalnya pihak tergugat mengakui gugatan, pihak penggugat mengajukan alat bukti, dan seterusnya.

Kelima, Pengetahuan tentang pengalaman yakni berupa kesimpulan berdasarkan pengetahuan umum yang digunakan untuk menilai peristiwa yang diajukan atau yang telah terbukti. Misalnya pekerja yang sedang melakukan aksi pemogokan sudah pasti tidak dapat melakukan pekerjaan.

Keenam, Pembuktian dalam hukum acara mempunyai arti yuridis yang mempunyai makna memberi dasar-dasar yang cukup kepada hakim

${ }^{32}$ Lalu Husni, Penyelesaian Perselisihan Hubungan Industrial melalui Pengadilan dan di Luar Pengadilan, Raja Grafindo Persada, Jakarta, 2004, h. 104-105. 
yang memeriksa perkara yang bersangkutan guna memberi kepastian tentang kebenaran peristiwa yang diajukan. Dalam ilmu hukum tidak dimungkinkan ada pembuktian yang logis dan mutlak yang berlaku bagi setiap orang serta menutup segala kemungkinan dari bukti lawan, akan tetapi merupakan pembuktian konvensional yang bersifat khusus, pembuktian dalam arti yuridis tidak menuju kepada kebenaran yang bersifat mutlak.

Kebenaran yang dicari dalam acara perdata adalah kebenaran formil yang didasarkan pada bukti-bukti formal yang ada, serta hakim tidak boleh menjatuhkan putusan di luar yang diminta oleh pihak yang bersengketa, yang wajib membuktikan atau mengajukan alat bukti adalah para pihak yang berperkara, yakni penggugat dan tergugat, terutama penggugat wajib membuktikan peristiwa yang diajukannya, dan tergugat berkewajiban membuktikan bantahannya. Karena itu jika penggugat tidak dapat membuktikan peristiwa yang diajukannya, ia harus dikalahkan, dan apabila tergugat tidak dapat membuktikan bantahannya maka ia pula harus dikalahkan.

Proses beracara pada PHI adalah proses beracara perdata, menurut ketentuan hukum acara perdata, hakim terikat oleh alat bukti yang sah sistem pembuktian positif, yang berarti hakim hanya boleh mengambil keputusan berdasarkan alat bukti yang ditentukan oleh undang-undang sebagai sistem pembuktian positif.

Macam-Macam Alat Bukti dalam Acara Perdata adalah: ${ }^{33}$

Pertama, Alat Bukti Tertulis. Alat bukti tertulis atau surat ialah segala sesuatu yang memuat tandatanda bacaan yang dimaksudkan untuk mencurahkan isi hati atau menyampaikan buah pikiran seseorang dan dipergunakan untuk pembuktian. Surat sebagai alat bukti yang sah dibagi menjadi dua, yakni surat yang merupakan akta dan surat yang bukan akta. Sementara itu akta sendiri dibagi menjadi dua akta autentik dan akta di bawah tangan.

Akta autentik sebagai alat bukti diberi tanda tangan yang memuat peristiwa yang menjadi dasar suatu hak atau perikatan, yang dibuat sejak semula dengan sengaja untuk pembuktian. Dalam hubungan kerja beberapa perjanjian/ketentuan yang dibuat oleh

${ }^{33}$ Hari Sasangka, Hukum Pembuktian dalam Perkara Perdata, Mandar Maju, Bandung, 2005, h. 40. para pihak dapat digolongkan dalam pengertian akta autentik, seperti perjanjian kerja, perjanjian kerja bersama, dan peraturan perusahaan. Alat bukti tertulis dalam acara perdata harus dibubuhi dengan materai.

Kekuatan pembuktian akta autentik adalah sempurna. Namun demikian, jika terdapat bukti bahwa dalam pembuatanya terdapat cacat yuridis, maka akta tersebut dapat dilumpuhkan oleh bukti lawan.

Akta di bawah tangan adalah akta yang sengaja dibuat waktu pembuktian oleh para pihak tanpa bantuan dari seorang pejabat. Akta di bawah tangan hanya dapat diterima sebagai permulaan bukti tertulis.

Kedua, Alat Bukti Saksi. Kesaksian adalah kepastian yang diberikan kepada hakim di persidangan tentang peristiwa yang disengketakan dengan jalan memberitahukan secara lisan dan pribadi oleh orang yang bukan salah satu pihak dalam perkara yang dipanggil di persidangan. Keterangan yang diberikan oleh saksi harus tentang peristiwa atau kejadian yang dialaminya sendiri. Keterangan saksi harus diberikan secara lisan dan pribadi di persidangan sehingga tidak dapat diwakilkan atau dibuat secara tertulis. Keterangan saksi saja tanpa alat bukti lainya tidak dianggap sebagai pembuktian yang cukup, seorang saksi bukan saksi, unus testis nullus testis. Kekuatan pembuktian dari kesaksian seorang saksi saja belum sempurna, karena itu, gugatan harus ditolak jika penggugat dalam mempertahankan dalil gugatannya hanya mengajukan seorang saksi tanpa didukung oleh alat bukti lain.

Saksi sangat penting bagi para pihak yang bersengketa untuk membuktikan dalil-dalilnya, karena itu, saksi yang dipanggil secara patut harus datang ke persidangan. Jika saksi masih mempunyai hubungan keluarga sedarah atau semenda sampai derajat ketiga dari pihak-pihak yang bersengketa atau saksi menjalin hubungan kerja.

Ketiga, Alat Bukti Persangkaan. Persangkaan merupakan alat bukti tidak langsung yang ditarik dari alat bukti lain. Karenanya ada anggapan bahwa persangkaan sebenarnya bukan merupakan alat bukti yang berdiri sendiri, dengan alasan yang dipakai sebagai alat bukti bukan persangkan itu sendiri tapi alat bukti lain. Dengan demikian, dalam setiap alat bukti dapat menjadi persangkaan, bahkan hakim 
dapat menggunakan peristiwa prosedurar maupun peristiwa notoir sebagai persangkaan.

Keempat, Alat Bukti Pengakuan. Pengakuan khususnya di depan persidangan, merupakan keterangan sepihak, baik secara lisan maupun tulisan, yang tegas dan dinyatakan oleh salah satu pihak dalam persidangan, yang membenarkan baik secara keseluruhan atau sebagian dari suatu peristiwa, hak, atau hubungan hukum yang diajukan oleh lawannya, yang mengakibatkan pemeriksaan lebih lanjut oleh hakim menjadi tidak perlu lagi. Oleh karena itu, pengakuan merupakan alat bukti yang menentukan yang tidak memerlukan pembuktian lawan. Jika tergugat mengakui tuntutan penggugat, hakim harus mengabulkan tuntutan penggugat. Pengakuan tergugat membebaskan penggugat untuk membuktikan lebih lanjut.

Kelima, Alat Bukti Sumpah. Sumpah merupakan suatu pernyataan khidmat yang diberikan atau diucapkan pada waktu memberi janji atau keterangan dengan mengikat akan sifat Maha Kuasa Tuhan, dan percaya bahwa siapa yang memberi keterangan atau janji yang tidak benar akan mendapatkan hukuman dari-Nya. Dengan demikian sumpah merupakan perbuatan yang sifatnya religius yang digunakan untuk kepentingan peradilan. Sumpah sebagai alat bukti dalam persidangan dibagi menjadi tiga jenis, antara lain sumpah pelengkap (suppletoir), sumpah pemutus yang bersifat menentukan (decisoir), dan sumpah penaksiran (aestimatoir). Sumpah suppletoir atau pelengkap merupakan sumpah yang diperintahkan oleh hakim karena jabatannya kepada salah satu pihak untuk melengkapi pembuktian peristiwa yang menjadi sengketa sebagai dasar putusannya. Jadi untuk dapat memerintahkan sumpah suppletoir kepada salah satu pihak, harus ada pembuktian permulaan terlebih dahulu, tetapi bukti tersebut belum mencukupi dan tidak ada alat bukti lain, sehingga apabila ditambahkan dengan sumpah suppletoir pemeriksaan perkara menjadi selesai dan hakim dapat menjatuhkan putusannya, misalnya jika hanya ada seorang saksi saja.

Sumpah penaksiran (aestimatoir) adalah sumpah yang diperintahkan oleh hakim karena jabatannya kepada penggugat untuk menentukan jumlah uang ganti kerugian. Dalam praktik seringkali ditemukan jumlah ganti kerugian yang dituntut oleh salah satu pihak tidak jelas jumlahnya, serta tidak ada cara lain untuk menentukan jumlah gati kerugian tersebut kecuali dengan penaksiran.

Sumpah pemutus (decisoir) adalah sumpah yang dibebankan atas permintaan salah satu pihak kepada lawannya. Berbeda dengan sumpah suppletoir, sumpah decisoir dapat dibebankan atau diperintahkan meskipun tidak ada pembuktian sama sekali. Pihak yang meminta lawannya mengucap sumpah disebut deferent, sedangkan pihak yang harus bersumpah disebut delaat. Menolak mengucapkan sumpah decisoir akan mengakibatkan dikalahkannya pihak yang menolak dilakukannya sumpah tersebut. Sumpah decisoir ini dapat berupa sumpah pocong, sumpah mimbar.

Selain kelima alat bukti tersebut di atas, terdapat pula alat bukti lain yang dapat dipergunakan untuk memperoleh kepastian mengenai kebenaran suatu peristiwa yang menjadi sengketa, misalnya pemeriksaan setempat dan keterangan ahli. ${ }^{34}$

Keenam, Pemeriksaan Setempat. Pemeriksaan setempat merupakan pemeriksaan mengenai perkara oleh hakim karena jabatannya yang dilakukan di luar gedung atau tempat kedudukan pengadilan, agar hakim dapat melihat sendiri memperoleh gambaran atau keterangan yang memberi kepastian tentang peristiwa yang menjadi sengketa. Pemeriksaan setempat lazimnya dilakukan pada perkara perdata yang obyeknya sengketa benda tetap, seperti tanah yang dilakukan untuk meyakinkan hakim mengenai kondisi obyek sengketa serta batas-batasnya. Oleh karena itu, dalam sengketa hubungan industrial hal ini tidak relevan.

Ketujuh, Keterangan Ahli. Selain keterangan saksi, hakim juga dapat meminta keterangan dari seorang ahli yang lazim disebut dengan istilah saksi ahli dalam pembuktian. Keterangan ahli adalah keterangan dari pihak ketiga yang obyektif dan bertujuan untuk membantu hakim dalam pemeriksaan guna menambah pengetahuan hakim.

Pada umumnya, hakim menggunakan keterangan seorang ahli untuk memperoleh pengetahuan yang lebih mendalam tentang sesuatu yang hanya diketahui oleh seorang ahli, atas permintaan salah satu pihak atau karena jabatannya pengadilan dapat mengangkat seorang ahli.

${ }^{34}$ Lalu Husni, Penyelesaian Perselisihan Hubungan Industrial melalui Pengadilan dan di Luar Pengadilan, Raja Grafindo Persada, Jakarta, 2004, h. 115-118. 
Pada PHI peranan ahli akan sangat membantu hakim untuk menemukan kebenaran terhadap kasus yang diperiksa. Oleh karena itu, dalam UndangUndang No. 2 Tahun 2004 menyebutkan bahwa majelis hakim dapat memanggil saksi atau ahli untuk hadir dalam persidangan guna diminta dan didengar keteranganya. Setiap orang yang dipanggil untuk menjadi saksi atau saksi ahli berkewajiaban untuk memenuhi panggilan dan memberikan kesaksianya di bawah sumpah demikian pentingnya saksi atau saksi ahli oleh karena itu, jika pihak-pihak yang telah dipanggil sebagai saksi atau saksi ahli tidak memenuhi panggilan tersebut tanpa alasan yang sah dapat dikenakan pidana kurungan paling sedikit 1 (satu) bulan dan paling lama 6 (enam) bulan dan/ atau denda paling sedikit Rp 10.000.000,- (sepuluh juta rupiah) dan paling banyak Rp 50.000.000,- (lima puluh juta rupiah).

\section{Putusan Pengadilan Hubungan Industrial}

Dalam persidangan perselisihan hubungan industrial, pasti hakim akan menjatuhkan suatu putusan terhadap perselisihan hubungan industrial yang sedang dipersidangkan. Putusan PHI pada Pengadilan Negeri mengenai perselisihan kepentingan dan perselisihan antar serikat pekerja/ serikat buruh dalam satu perusahaan merupakan putusan akhir dan bersifat tetap (final and binding). Sementara itu, putusan PHI mengenai perselisihan hak dan perselisihan pemutusan hubungan kerja mempunyai kekuatan hukum tetap apabila tidak diajukan permohonan kasasi ke Mahkamah Agung dalam waktu selambat-lambatnya empat belas hari..$^{35}$

Penyelesaian suatu sengketa atau menjatuhkan putusan atas suatu sengketa, hakim harus mengetahui terlebih dahulu secara lengkap dan obyektif tentang duduk perkara yang sebenarnya dapat diketahui dari proses pembuktian. Setelah suatu peristiwa dinyatakan terbukti, hakim harus menemukan hukum dari peristiwa yang disengketakan dan dilanjutkan dengan pemberian putusan. Putusan hakim adalah suatu pernyataan yang oleh hakim sebagai pejabat negara yang diberi wewenang untuk itu, diucapakan di persidangan dan bertujuan untuk mengakhiri atau menyelesaikan suatu perkara atau sengketa

${ }^{35}$ Zaeni Asyhadie, Peradilan Hubungan Industrial, Raja Grafindo Persada, Jakarta, 2009, h. 125. perselisihan hubungan industrial antar para pihak yang berselisih. ${ }^{36}$

Pasal 100 Undang-Undang No. 2 Tahun 2004 tentang Penyelesaian Perselisihan Hubungan Industrial disebutkan bahwa dalam mengambil putusan Majelis Hakim mempertimbangkan hukum, perjanjian yang ada, kebiasaan, dan keadilan:

Pertama, Hukum. Maksudnya adalah hukum positf yang mengatur di bidang ketenagakerjaan serta hukum peraturan perundang-undangan yang lain yang berkaitan dengan hukum ketenagakerjaan.

Kedua, Perjanjian yang ada. Maksudnya adalah perjanjian kerja maupun perjanjian kerja bersama. Perjanjian kerja adalah perjanjian kerja yang dibuat antara pekerja dengan pengusaha atau pemberi kerja yang memuat syarat-syarat kerja, hak dan kewajiban para pihak. Perjanjian kerja bersama adalah perjanjian yang merupakan hasil perundingan antara serikat pekerja atau beberapa serikat pekerja yang terdaftar dalam instansi yang bertanggungjawab di bidang ketenagakerjaan dengan pengusaha, atau beberapa perkumpulan pengusaha yang memuat syaratsyarat kerja, hak dan kewajiban kedua belah pihak. Sementara itu peraturan perusahaan tidak termasuk dalam perjanjian, karena dibuat secara sepihak oleh pengusaha yang berisikan tentang syarat-syarat kerja dan tata tertib perusahaan.

Ketiga, Kebiasaan. Adalah hukum tidak tertulis yang timbul dalam praktek penyelenggaraan hubungan kerja. Kebiasaan menjadi sumber hukum ini penting untuk mengisi kekosongan hukum yang tidak diatur dalam peraturan perundang-undangan yang ada maupun perjanjian yang dibuat para pihak.

Keempat, Keadilan. Adalah sebagai penekanan dari dasar pertimbangan hakim yang tidak hanya didasarkan pada pertimbangan hukum, perjanjian yang telah dibuat para pihak, tetapi juga kebiasaan sebagaimana telah disebut di atas, sehingga dasar pertimbangan hukum seperti itu akan melahirkan perasaan keadilan yang sesuai dengan keadilan masyarakat. ${ }^{37}$

Putusan PHI dibacakan oleh majelis hakim dalam sidang terbuka untuk umum, dalam hal ada pihak yang tidak hadir dalam persidangan maka

${ }^{36}$ Lalu Husni, Penyelesaian Perselisihan Hubungan Industrial melalui Pengadilan dan di Luar Pengadilan, Raja Grafindo Persada, Jakarta, 2004, h. 119.

${ }^{37}$ Ibid., h. 119-120. 
Majelis Hakim dapat memerintahkan kepada panitera pengganti untuk menyampaikan pemberitahuan putusan kepada pihak yang tidak hadir tersebut.

Ketentuan mengenai persyaratan isi putusan $\mathrm{PHI}$ diatur dalam Pasal 102 ayat (1) Undang-Undang No. 2 Tahun 2004, sebagai berikut: Kepala putusan berbunyi DEMI KEADILAN BERDASARKAN KETUHANAN YANG MAHA ESA; Nama, jabatan, kewarganegaraan, tempat kediaman atau tempat kedudukan para pihak yang berselisih; Ringkasan permohonan/penggugat dan jawaban termohon/ tergugat yang jelas; Pertimbangan terhadap setiap bukti dan data yang diajukan, hal yang terjadi dalam persidangan selama sengketa diperiksa; Alasan hukum yang menjadi dasar putusan; Amar putusan; Hari, tanggal putusan, nama hakim, hakim Ad-Hoc yang memutus, nama panitera, serta keterangan tentang ketidakhadiran para pihak; Tidak dipenuhinya salah satu ketentuan di atas, dapat menyebabkan batalnya putusan PHI.

\section{PENUTUP}

\section{Kesimpulan}

Penyelesaian perselisihan hubungan industrial melalui PHI mempunyai beberapa karakteristik yang harus diperhatikan oleh pencari keadilan dalam penyelesaian perselisihan hubungan industrial karena ciri-ciri tersebut secara limitatif diatur dalam UndangUndang No. 2 Tahun 2004, adapun karakteristik tersebut meliputi Obyek dan Subyek perselisihan, Hukum acara yang digunakan dalam perselisihan hubungan industrial,dan kuasa hukum serikat pekerja/serikat buruh dan organisasi pengusaha dapat bertindak sebagai kuasa hukum di persidangan PHI untuk mewakili kepentingan anggotanya, ciriciri tersebutlah yang membedakan penyelesaian perselisihan hubungan industrial melalui pengadilan hubungan industral dengan penyelesaian perkara perdata pada umum.

\section{Rekomendasi}

Penyelesaian perselisihan hubungan industrial melalui PHI seharusnya tidak hanya dibentuk pada ibukota Provinsi saja tetapi sepatutnya dibentuk di seluruh Pengadilan Negeri di setiap Kabupaten/Kota hal ini untuk memberikan pelayanan kemudahan bagi pencari keadilan perselisihan hubungan baik bagi pekerja maupun pengusaha sehingga asas cepat, sederhana dan biaya murah dapat tercapai.

\section{DAFTAR PUSTAKA}

\section{Peraturan Perundang-undangan:}

Undang-Undang Dasar Negara Tahun 1945.

Undang-Undang Nomor 21 Tahun 2000 tentang Serikat Pekerja/Serikat Buruh, Lembaran Negara Tahun 2000 Nomor 131, Tambahan Lembaran Negara Nomor 3989.

Undang-Undang Nomor 13 Tahun 2003 tentang Ketenagakerjaan, Lembaran Negara Tahun 2003 Nomor 39, Tambahan Lembaran Negara Nomor 4279.

Undang-Undang Nomor 2 Tahun 2004 tentang Penyelesaian Perselisihan Hubungan Industrial, Lembaran Negara Tahun 2004 Nomor 6, Tambahan Lembaran Negara Nomor 4356.

Peraturan Menteri Tenaga Kerja dan Transmigrasi RI Nomor 17 Tahun 2014 tentang Pengangkatan dan Pemberhentian Mediator Hubungan Industrial serta Tata Kerja Mediasi, Berita Negara Tahun 2014 Nomor 1435.

\section{Buku:}

Akademis, Naskah, 2007, Penyelesaian Perselisihan Hubungan Industrial, Mahkamah Agung RI: Puslitbang Hukum dan Peradilan, Badan Litbang Diklat Kumdil.

Algra, Mr. N.E., et.al., 1983, Kamus Istilah Hukum Fockema Andreae Belanda-Indonesia, Bandung: Bina Cipta.

Asyhadie, Zaeni, 2009, Peradilan Hubungan Industrial, Jakarta: Raja Grafindo Persada.

Danuhandoko, I.P.M., 2006, Terminologi Hukum Inggris-Indonesia, Cetakan Keempat, Jakarta: Sinar Grafika, Jakarta.

Depdiknas, Tim Pusat Bahasa, 2008, Kamus Bahasa Indonesia, Jakarta: Pusat Bahasa Departemen Pendidikan Nasional.

Goodpaster, Gary, 1995, Tinjauan terhadap Penyelesaian Sengketa, Jakarta: Ghalia Indonesia.

Halley, Nolan, 1992, Alternative Dispute Resolution, St. Paul: West Publishing.

Head, John W., 1997, Pengantar Umum Hukum Ekonomi, Jakarta: Proyek ELIPS. 
Husni, Lalu, 2004, Penyelesaian Perselisihan Hubungan Industrial melalui Pengadilan dan di Luar Pengadilan, Jakarta: Raja Grafindo Persada.

Koesnoe, Moh., Catatan-Catatan terhadap Hukum Adat Dewasa Ini, Surabaya: Airlangga University Pers.

Mahadi, 1991, Falsafah Hukum Suatu Pengantar, Bandung: Alumni.

Marzuki, Peter Mahmud, 2005, Penelitian Hukum, Jakarta: Prenada Media.

More, Cristopher W., 1995, Mediasi Lingkungan, Jakarta: Indonesia Center for Environmental Law and CDR Associates. 1996, The Mediation Process Practical Strategies for Resolving Conflict, Second Edition, San Francisco: Jossy Bas. , 2012, The Mediation Prosess dalam Pengantar Mediasi, Jakarta: Pusat Mediasi Nasional.

Mulyadi, Lilik dan Agus Subroto, 2011, Penyelesaian Perkara Pengadilan Hubungan Industrial dalam Teori dan Praktik, Bandung: Alumi.

Perdana, Surya, 2008, Disertasi, "Mediasi Merupakan Salah Satu Cara Penyelesaian Perselisihan Pemutusan Hubungan Kerja pada Perusahaan di
Sumatera Utara", Medan: Program Pascasarjana Universitas Sumatera Utara.

Rahardjo, Satjipto, 1986, Ilmu Hukum, Bandung: Alumni.

Riskin, Leonard L. dan James E. Westbrook, 1987, Dispute Resolution and Lawyers, St. Paul: West Publishing.

Roszkowki, Mark E., 1997, Business Law: Principle, Cases and Policy, United States: Addison Welwy Longman Inc.

Runtung, 2002, Disertasi, "Keberhasilan dan Kegagalan Penyelesaian Sengketa Alternatif (Studi Mengenai Masyarakat Karo di Kabanjahe dan Berastagi)", Medan: Program Pascasarjana Universitas Sumatera Utara.

Sasangka, Hari, 2005, Hukum Pembuktian dalam Perkara Perdata, Bandung: Mandar Maju.

Soebagjo, Felix O. (ed.), 1995, Arbitrase di Indonesia, Seri Dasar-Dasar Hukum Ekonomi 2, Jakarta: Ghalia Indonesia.

Usman, Rachmadi, 2003, Pilihan Penyelesaian Sengketa di Luar Pengadilan, Bandung: Citra Aditya Bakti.

Widjaya, Gunawan dan Ahmad Yani, 2000, Seri Hukum Bisnis: Hukum Abitrase, Jakarta: Raja Grafindo Persada. 